\title{
A Model for Academics' Perceptions of Organizational Structure, Individual Performance and Turnover Intention ${ }^{{ }^{*}}$
}

\author{
Muhammed ZINCIRLi \\ Assist. Prof. Dr., Firat University, \\ Faculty of Education, Department of Educational Sciences \\ mzincirli@firat.edu.tr \\ Orcid ID: https://orcid.org/0000-0003-0716-6794 \\ Muhammed TURHAN \\ Prof. Dr., Firat University, \\ Faculty of Education, Department of Educational Sciences \\ mturhan@firat.edu.tr \\ Orcid ID: https://orcid.org/0000-0003-4077-6471
}

\begin{abstract}
The study aims to develop a model for the relationship between the current organizational structure, along with some variables, in universities, which are an educational organization, and the perceptions of academics' individual performance and turnover intention. While the population of research is composed of all universities carrying out educational activities in Turkey, the sample of research consists of a total of 37 universities selected by quota sampling method by taking into account certain criteria. Analyses were performed on the data obtained from a total of 1242 academics working at these universities. Following the analyses, it was determined that there was a positive interaction between the enabling organizational structure and the academics' perceptions of individual performance and other positive variables, and that a positive interaction existed between the coercive organizational structure and the academics' perceptions of the turnover intention and other negative variables. Moreover, it was found that the positive relationship of the coercive organizational structure with the turnover intention and other negative variables was stronger than the negative relationship of the enabling organizational structure. Based on these results, it was concluded that it is necessary, but not

\footnotetext{
${ }^{1}$ Article Arrival/Acceptance Date: 30.12.2020 / 11.02.2021

*This study was produced from the doctoral dissertation of Muhammad ZINCİRLİ, which was completed under the supervision of Prof. Dr. Muhammad TURHAN

Reference Information: Zincirli, M. and Turhan, M. (2021). A model for academics' perceptions of organizational structure individual performance and turnover intention. Kahramanmaraş Sütçü Imam University Journal of Social Sciences, 18(1), 262-296. DOI: $10.33437 /$ ksusbd.849927
} 
sufficient, to have an enabling organizational structure in order to increase the positive feelings, attitudes and behaviours of academics.

Keywords: Academician, Organizational Structure, Individual Performance, Turnover Intention, Model

\section{Akademisyenlerin Örgütsel Yapı, Bireysel Performans ve İşten Ayrılma Niyeti Algılarına Yönelik Bir Model}

\section{Öz}

$\mathrm{Bu}$ çalışmanın amacı; bir eğitim örgütü olan üniversitelerdeki mevcut örgüt yapısıyla birlikte bazı değişkenlerin akademisyenlerin bireysel performansı ve işten ayrılma niyeti algıları arasındaki ilişkiye yönelik bir model geliştirmektir. Araştırmanın evrenini, Türkiye'de eğitim öğretim faaliyetlerini yürüten tüm üniversiteler, örneklemini ise belirli kriterlerin dikkate alındığı kota örnekleme yöntemi ile seçilen toplamda 37 üniversite oluşturmaktadır. Bu üniversitelerde görev yapan toplam 1242 akademisyenden elde edilen veriler üzerinde analizler yapılmıştır. Yapılan analizler sonucunda; kolaylaştırıcı örgüt yapısı ile akademisyenlerin bireysel performans ve diğer olumlu değişkenlere dair algıları arasında pozitif yönlü bir etkileşim olduğu, engelleyici örgüt yapısı ile akademisyenlerin işten ayrılma niyeti ve diğer olumsuz değiş̧kenlere dair algıları arasında pozitif yönlü bir etkileşim olduğu tespit edilmiştir. Ayrıca engelleyici örgüt yapısının işten ayrılma niyeti ve diğer olumsuz değişkenler ile pozitif yönlü ilişkisinin, kolaylaştırıcı örgüt yapısının negatif yönlü ilişkisinden daha güçlü olduğu belirlenmiştir. Bu sonuçlara dayalı olarak, akademisyenlerin olumlu duygu, tutum ve davranışlarının artırılabilmesi için örgüt yapısının kolaylaştırıcı olmasının gerekli olduğu ama yeterli olmadığı sonucuna ulaşılmıştır.

Anahtar Kelimeler: Akademisyen, Örgüt Yapısı, Bireysel Performans, İşten Ayrilma Niyeti, Model.

\section{INTRODUCTION}

When we look at the structure of social organizations such as universities, which are among the educational organizations, we see that many of them have bureaucratic characteristics, whether we like it or not (Buluç, 2009: 77). We can say that universities have different targets. In fact, universities are expected to direct the society and to do this with both scientific activities and technological infrastructure studies, and to contribute to the culture and to help the culture reach the next generations, and to raise individuals with sufficient expertise in appropriate professions (Aypay, 2003). We can touch upon many factors for 
achieving these targets within the existing processes. One of these factors is the structures in universities. These structures must have the qualities that contribute to the realization of the targets. Structures in universities can be directly related to academics' behaviours in this sense. There are many scientific studies on this topic (academics' behaviours, and organizational structure or situation in universities) (Acer Karataş, 2015; Antalyal1, 2008; Aypay, 2001; Balc1, 2003; Berger, 1997; Bergquist, 1992; Bess, 1984; Birnbaum, 1988; Karip, 2005; Öz, 2015). Considering the existing studies on the topic, different models and approaches can be mentioned about the organizational structure in universities (Blau, 1973; Childers, 1981; Astin and Scherrei, 1984; Deal, 1987; Birnbaum, 1988). Hoy and Sweetland (2000/2001), who evaluated the results of the researches discussing the views on bureaucracy and the coercive and enabling bureaucracy approach introduced by Adler and Borys (1996), interpreted the bureaucratic structure with a different philosophy. Educational institutions are bureaucratic structures, as they have many of the characteristics of bureaucracy (e.g. levelling of authority, technical competence, objective standards, division of labour, and rules) (Hoy, 2003). In this context, as they carry the traces of a bureaucratic structure, the rules to be followed, procedures, role structures and understanding of hierarchical management have been effective in the behaviours of educators and their perceptions of their profession (Cerit, 2013). This can be anticipated for academics in universities as well. Hoy and Sweetland (2001) examined the administrative structure of educational institutions within the framework of two basic concepts of bureaucracy: formalization and centralization. Hoy and Sweetland (2001) report that with the existence of a bureaucratic structure in educational institutions, cooperation and effective communication between employees cannot be possible, and hence, the efforts of educators who become isolated will not be sufficient to improve education, and that educators with low self-efficacy levels may adopt an attitude that avoids taking responsibility for student learning. Hoy and Sweetland (2000/2001) note that the structures aiming to punish those who do not obey the rules, and to control the behaviours, that is, bearing the traces of the negative bureaucratic structure refer to "coercive formalization", while the structures that aim to contribute to employees in the solution of the problems they face while performing their duties, and that bear the traces of positive bureaucracy refer to "enabling formalization". Based on these considerations, the organizational structure, which is one of the main variables of this study, was formalized within the framework of the organizational structure theory that was put forward by the definition of Hoy and Sweetland. Bureaucratic structures of universities were analysed in two dimensions: enabling and coercive.

It is possible to see the traces of the bureaucratic structure in education systems, not only in our country, but also in other countries, as the education system has a centralized structure in general (Yücel, 1999). It is obvious that the 
rules and procedures formalized around the hierarchy will also be effective in formalizing the behaviours in universities within education systems. According to these rules and procedures, not only the behaviors but also the content of the education provided in universities are defined (McGuigan and Hoy, 2006). In this context, it is possible that the hierarchy, rules and procedures, which are required by the bureaucratic structure, have an effect on the behaviours and professional perceptions of academics, because universities are an organization bearing the traces of the bureaucratic structure (Cerit, 2013). The organizational structure in universities can have an impact on academics' individual performance and turnover intention as well as on many other variables. While organizational structure has a positive effect on some variables, it may sometimes have a negative effect, as well it is impossible for us to understand all the variables associated with bureaucratic structure in universities. At this point, some variables that are considered to be related to organizational structure were determined by taking into account the theories, application and research results and assumptions in the field. We can explain these variables discussed within the scope of the study as follows:

Collective Efficacy: According to Bandura (1997), collective efficacy is a group's accepted belief in their ability to organize and manage the works needed to create certain levels of skills and the stages of these studies. In other words, collective efficacy reflects the belief in whether the thoughts and activities needed to accomplish the task given can be organized effectively (Goddard, Hoy, and Hoy, 2004). The management structure in organizations has an effect on collective efficacy. Academics' belief in working together is definitely related to the organizational structure of that university. For this reason, it will be useful for university administrations to adopt a management style by producing policies that will contribute to the collective efficacy of academics.

Individual-Organization Fit: The behaviour, which is also expressed as individual-organization fit or person-organization fit, is that the individual and the organization in which he/she is have harmonious expectations or have the same characteristics (Kristof, 1996: 3). In a broader sense, person-organization fit is the extent to which people's values, beliefs, norms and expectations are harmonious with the work they perform (Yahyagil, 2005: 137). Kraimer (1997) defines individual-organization fit as the harmony between the norms and values of the organization and the values of the employees. Harmonization of academics with the universities in terms of values and norms will contribute to the individual-organization fit. This will also be positively reflected on both individual performance and educational services.

Job Satisfaction: Based on the studies on job satisfaction in the literature, an employee's satisfaction from his/her job is the emotional state resulting from what 
he/she wants to get from his/her job (Işıkhan, 2004). Job satisfaction is basically defined as what an employee feels about his/her job or different aspects of it, and the positive emotional level of these feelings (Spector, 1997: 2). Job satisfaction, which is a significant perception for every employee, is highly important for academics. Job satisfaction interacts with many perceptions of academics.

Organizational Commitment: Organizational commitment was defined by Meyer and Allen (1991) as "an employee's regular attendance at work, protection of the values of the workplace and integration with its goals". It is also defined as the desire on the part of an employee to remain a member of the organization (Manion, 2005), loyalty and strict commitment to the organization (Daft and Marcic, 2009), the member's belief in the aims of the organization and level of remaining a member of organization (Mathis and Jackson, 2008). Commitment is addressed under three categories with the developed theories. These are called affective commitment, normative commitment, and continuance commitment (Allen and Meyer, 1996). When these three types of commitment are examined, it can be suggested that academics in universities may have continuance commitment considering the fact that they have an expectation of retirement according to their personal rights as a result of the time during which they work, and they may have affective commitment to adopt the mission and vision of the university and to contribute to them. The commitment that may be established by academics' work for many years at the same university, harmonization between their own values and the values of the university, and their internalization of these values, and interaction with them can be considered as a normative commitment behaviour.

Burnout: With the most acknowledged definition, it is a mental and physical syndrome that involves long-term feelings of hopelessness, helplessness, exhaustion and fatigue that occur in individuals as a result of a certain interaction, and negative attitudes towards other people in the work and social environment where they live in (Maslach and Jackson, 1981). The level of burnout will affect academics' interest in job in universities. Academics having a high level of burnout will be less interested in work and will make less contribution to the accomplishment of goals. Creation of the necessary conditions, by administrators in universities, to keep the level of burnout at the lowest level will serve the desired goals by increasing the interest in the job.

Stress: According to Cüceloğlu (1994: 28), stress, which is defined as the effort exhibited above the physical and psychological limits of a person due to the unsuitable conditions around him/her, is described, by another definition, as the reaction of the body against the pressures from internal and external sources (Altıntaş, 2003: 14). Stress, which is an increasingly important issue in life, is also significant for the academic community. Because of their multi-dimensional 
structure, many factors such as the workload of academics, the problems caused by their career planning, and the difficulties experienced in scientific activities may create an environment where the feeling of stress will emerge. This study especially tried to determine the relationship of the organizational structure and other individual variables with stress.

Interest in Job: Interest in job is defined as the degree of importance of working in a person's life. Some people see work as an important part of their lives, while for others it may seem very meaningless. Interest in job is associated with the cognitive aspect of attitude (Güven, 2002). It is possible to suggest that interest in job or attitude, which we can also be expressed as commitment to work, is an issue that needs to be highlighted, particularly in universities, in terms of educational services. The positive attitude of academics towards their work will enable many other organizational behaviours to be positively affected. Since variables such as organizational commitment, job satisfaction, and motivation are significantly effective in high interest in job, academics' interest in their job is based on their perception of these variables.

Turnover Intention: Turnover intention is defined as the attitudes and behaviours of employees towards quitting their jobs (Avc1, 2008; Breukelen, 1988; Schyns, Torka and Gössling, 2007). There are different definitions of the concept of turnover in the literature. According to the definition by Rusbel, Farrell and Rogers (1988), turnover is the actions that employees perform when they are not satisfied with the working conditions. Based on the behaviours associated with the turnover intention, it can be put forward that some behaviours may affect academics' turnover intention. Particularly, academics' job satisfaction and commitment to their organizations are effective in their perception of turnover intention. Therefore, job satisfaction and organizational commitment, one of the other variables of our study, will be to the point for having more objective results.

Organizational Silence: It can be defined as employees' deliberate avoidance of expressing their opinions on the events, problems and issues in the organization, for refraining from possible reactions and being a problematic person, and for being subject to others' opinions or due to the thought that their views will not make a difference (Taşkıran, 2011). In other words, it is the fact that individuals in the organization do not share their views and concerns about problems (Morrison and Milliken, 2003). Academics working at universities, that are an educational institution aiming to raise individuals with self-confidence and high critical thinking skills, are expected to have a low perception of organizational silence. 
Cynicism: It is a specific or general attitude caused by a sense of frustration, disappointment or distrust against unfavourable feelings and situations (Naus, 2007: 15). Organizationally, it is possible to define it as an individual's dissatisfaction with the organization, and the feeling of insecurity and disappointment towards the organization, and being alienated from the organization (Dean, Brandes, and Dharwadkar, 1998). Observing cynical behaviours in academics will have a negative effect on the efficiency of educational activities. Especially in universities that are homes to science, weak belief in positive attitudes such as honesty, moral values and merit, which are universal principles, will be accompanied by cynical behaviours. The fact that academics see their own interests superior to those of both the university where they work and of the education system may also lead to cynicism. Since cynicism is a concept that is not only independent of itself and is affected by many organizational behaviours, it will be endeavoured to determine how much it is influenced by these organizational behaviours for the purpose of this study.

The purpose of this study is to propose a hypothetical model for the variables that are predictors of academics' perceptions of organizational structure and their individual performance and turnover intention. Accordingly, it can be put forward that many criteria should be observed to evaluate academics' job performance. In the light of the studies conducted in the literature, the relationship between the variables and perceptions of organizational structure explained above and the individual performance and turnover intention of academics was addressed in this study. Especially, it was examined to what extent and direction the organizational structure along with the other variables were influential on the academics' individual performance and turnover intention.

The hypotheses determined for the purpose of the research are listed below.

H1: Coercive organizational structure has a negative effect directly and indirectly on academics' perception of individual performance.

H2: Enabling organizational structure has a positive effect directly and indirectly on academics' perception of individual performance.

H3: Coercive organizational structure has a positive effect directly and indirectly on academics' perception of turnover intention.

H4: Enabling organizational structure has a negative effect directly and indirectly on academics' perception of turnover intention. 


\section{METHOD}

\section{Model of research}

This study addressing the academics' perceptions of organizational structure and their individual performances adopts the survey model. Based on the most general definition by Karasar (2005: 118), survey models are the research models that aim to describe a situation that existed in the past or exists currently as it was/is. Survey research is a method that can be preferred to determine individuals' attitudes, actions, opinions and beliefs. However, the survey method is helpful in exploratory, descriptive, predictive and, in some cases, descriptive researches (Christensen, Johnson, and Turner, 2011/2015). Also, in this research, the models developed for organizational structure and various variables were tested with field application, and it was tried to reach results in this way. The correlational survey model, one of the survey models, was adopted to identify the relationships. Correlational survey models are used to determine the existence and extent of changes in variables that are thought to be inter-related (Karasar, 2005: 118). This study is a correlational survey model that intends to develop a hypothetical model for the variables that are predictors of academics' perceptions of organizational structure and their individual performance and turnover intention.

\section{Population and Sample}

The population of this study is composed of all universities within the borders of Turkey, while its sample consists of totally 37 universities including 25 state and 12 foundation universities that were selected by quota sampling method. It can be noted that the quota sampling method is the same as the stratified sampling method, except the fact that the units in each stratum are selected randomly without any criteria (Cochran, 1977: 372). When the units to be included in the sample from each stratum are determined impartially and orderly, it is possible to make generalizations about the population through the sample created, or the sample may have the capability of representing the population (Bailey, 1994: 218). For defining the universities to be included in the sample, the establishment year of the universities and their official status (state/foundation) were first taken into account. When there was more than one university with the defined characteristics, the universities to be included in the sample were randomly determined. Academics were randomly and impartially determined from the universities included in the sample. In the selection of academics, it was paid attention to reaching the academics from different units and departments in order to determine a homogeneous sample, taking into account the size of the universities.

$36.5 \%$ of 1242 academics participating in the research in line with these principles are female, and $63.5 \%$ are male. While $77.9 \%$ of the academics are 
married, $22.1 \%$ are single. In the age category, $41 \%$ of the participants are 20-35 years old, $42.4 \%$ of them are $36-50$ years old, $13.4 \%$ are $51-65$ years old, and $3.1 \%$ are over 65 years old. $80.4 \%$ of academics are employed in state universities, while $19.6 \%$ of them are employed in foundation universities. Considering the ratio of foundation universities to state universities in our country, this distribution is normal. $49.6 \%$ of academics work in universities established before 1992, and 20.5\% in the universities established between 1992 and 2006, and 30\% in universities established in 2006 and later. In terms of the academic titles of the participant academics, $17.3 \%$ are professors; $13.1 \%$ are associate professors; $24.9 \%$ are assistant professors, and $44.7 \%$ have other academic titles research assistant, specialist, lecturer, etc.). $78 \%$ of these academic staff work in faculties, and $4.5 \%$ in institutes, and $17.5 \%$ in other departments. $4.1 \%$ of the academics have a bachelor's degree, $24 \%$ have a master's degree and $71.9 \%$ have a doctor's degree.

Ethical permission of the study was obtained from Firat University noninterventional research ethics committee (Date and Number of Documents: 13/10/2015; 18/12).

\section{Data Collection Tools}

While the data collection tools were determined in accordance with the purpose of the research, similar scales in the literature were identified. The determined scales were examined in terms of the criteria such as their acceptance in the literature, the characteristics they measure, and their practicality, dimensions, number of items, suitability for the research methodology and response time, and it was decided which ones to use in the research. For the purpose of collecting research data, the scales of effectiveness of the school structure, collective efficacy, burnout, turnover intention, interest in job, organizational commitment, job satisfaction, stress, individual performance, cynicism and individual-organization fit were used. The properties of these scales are addressed under this title. Of the scales used, the burnout scale, job satisfaction scale and commitment scale were used in short form. Short forms are intended to be developed for the reasons such as intensive case values, use for surveying, research with more variables, sincerer answers of the participants, and decreased application time (Mumpower, 1964; Smith, McCarthy and Anderson, 2000). The short forms, on one hand, make their original form, that is, the long form more efficient and sufficient, and they on the other hand, allow for significant savings in the application time without an important decrease in reliability and validity values (Donders, 1997). These practical expectations and benefits also make short forms more favourable (Cole Rabin, Smith and Kaufman, 2004). In this study, the method of selecting items from the long form scales was used in a way not to harm the content validity. The most significant 
aspect in this method is to analyse the variable to be measured theoretically and to ground the item selection on the theoretical foundations of the subject. Another aspect is the re-analysis of the validity and reliability of the short-form scale. Therefore, while creating the short form scales used in the research, the exploratory and confirmatory factor analyses were conducted, after the item selection, to check whether the psychometric properties of the scales were adequate.

A pilot application was performed, to determine whether the research was properly understood by the target audience, because the sample of the research (academics) was different from the samples taken into account when developing the scales by the researchers. Exploratory and confirmatory factor analyses for the measurement tools were conducted on the data collected in the pilot application. This application was made on 340 academics working at Firat University. In this context, factor analyses were conducted through a statistical package program in order to use the scales previously used in other studies in this research, as well.

The psychometric properties of the measurement tools used for the variables discussed in the scope of the research are given in Table 1.

Table 1. Psychometric Properties of Data Collection Tools

\begin{tabular}{|c|c|c|c|c|c|}
\hline Title of Scale & $\begin{array}{l}\text { Developed/Ad } \\
\text { apted by }\end{array}$ & $\begin{array}{l}\text { KMO } \\
\text { and } \\
\text { Bartlett } \\
\text { test }\end{array}$ & $\begin{array}{l}\text { Exploratory } \\
\text { Factor } \\
\text { Analysis } \\
\text { (EFA) }\end{array}$ & $\begin{array}{l}\text { Item Factor } \\
\text { Loads }\end{array}$ & $\begin{array}{l}\text { Internal } \\
\text { Consistency } \\
\text { (Cronbach } \\
\text { Alpha) }\end{array}$ \\
\hline $\begin{array}{l}\text { Effectiveness } \\
\text { of School } \\
\text { Structure }\end{array}$ & $\begin{array}{l}\text { Hoy ve } \\
\text { Sweetland } \\
\text { (2001), } \\
\text { Buluç (2009), } \\
\text { Özer and } \\
\text { Dönmez } \\
\text { (2013) }\end{array}$ & $\begin{array}{l}\mathrm{KMO}= \\
.945, \\
\mathrm{p}=.000\end{array}$ & $\begin{array}{l}72.35 \% \text { of } \\
\text { the total } \\
\text { variance, } \\
\text { The first } \\
\text { dimension } \\
\text { (coercive } \\
\text { structure): } \\
41.20 \% \text { of } \\
\text { the variance, } \\
\text { The second } \\
\text { dimension } \\
\text { (enabling } \\
\text { structure): } \\
31.15 \% \text { of } \\
\text { the variance, }\end{array}$ & $\begin{array}{l}\text { The first } \\
\text { dimension } \\
\text { (coercive } \\
\text { structure; } \\
\text { six items): } \\
\text { in the } \\
\text { range of } \\
\text { “.61” to } \\
\text { " } 83 \text { ”, } \\
\text { The second } \\
\text { dimension } \\
\text { (enabling } \\
\text { structure; } \\
\text { six items): } \\
\text { in the } \\
\text { range of } \\
\text { “.75” to } \\
\text { “.85” }\end{array}$ & $\begin{array}{l}\text { The first } \\
\text { dimension } \\
\text { (coercive } \\
\text { structure): .90, } \\
\text { The second } \\
\text { dimension } \\
\text { (enabling } \\
\text { structure): .93, }\end{array}$ \\
\hline
\end{tabular}




\begin{tabular}{|c|c|c|c|c|c|}
\hline $\begin{array}{l}\text { Collective } \\
\text { efficacy }\end{array}$ & $\begin{array}{l}\text { Riggs, Warka, } \\
\text { Babasa, } \\
\text { Betancourt } \\
\text { and Hooker } \\
\text { (1994), } \\
\text { Öcal and } \\
\text { Aydın (2009), } \\
\text { Kilıç (2013) }\end{array}$ & $\begin{array}{l}\mathrm{KMO}= \\
.804 \\
\mathrm{p}=.000\end{array}$ & $\begin{array}{l}7 \text { items and } \\
\text { one } \\
\text { dimensions } \\
\text { accounting } \\
\text { for } 47.07 \% \\
\text { of the total } \\
\text { variance }\end{array}$ & $\begin{array}{l}\text { One } \\
\text { dimension: } \\
\text { in the } \\
\text { range of } \\
\text { “.54” to } \\
\text { “.79". }\end{array}$ & $\begin{array}{l}\text { One } \\
\text { dimension: .79 }\end{array}$ \\
\hline Burnout & $\begin{array}{l}\text { Maslach and } \\
\text { Jackson } \\
\text { (1981), } \\
\text { Ergin (1992) }\end{array}$ & $\begin{array}{l}\text { KMO = } \\
.905, \\
p=.000\end{array}$ & $\begin{array}{l}7 \text { items and } \\
\text { one } \\
\text { dimensions } \\
\text { accounting } \\
\text { for } 65.27 \% \\
\text { of the total } \\
\text { variance }\end{array}$ & $\begin{array}{l}\text { One } \\
\text { dimension: } \\
\text { in the } \\
\text { range of } \\
\text { ".44” to } \\
\text { “. } 75 \text { ". }\end{array}$ & $\begin{array}{l}\text { One } \\
\text { dimension: .91 }\end{array}$ \\
\hline $\begin{array}{l}\text { Turnover } \\
\text { Intention }\end{array}$ & $\begin{array}{l}\text { Bhuian, } \\
\text { Menguc, and } \\
\text { Borsboom } \\
\text { (2005), } \\
\text { Sulu (2010) }\end{array}$ & $\begin{array}{l}\mathrm{KMO}= \\
.722, \\
\mathrm{p}=.000\end{array}$ & $\begin{array}{l}3 \text { items and } \\
\text { one } \\
\text { dimensions } \\
\text { accounting } \\
\text { for } 82.60 \% \\
\text { of the total } \\
\text { variance }\end{array}$ & $\begin{array}{l}\text { One } \\
\text { dimension: } \\
\text { in the } \\
\text { range of } \\
\text { ".87” to } \\
\text { “.93". }\end{array}$ & $\begin{array}{l}\text { One } \\
\text { dimension: .88 }\end{array}$ \\
\hline Interest in job & $\begin{array}{l}\text { Kanungo } \\
(1982) \\
\text { Çakır (2001) }\end{array}$ & $\begin{array}{l}\mathrm{KMO}= \\
.712, \\
\mathrm{p}=.000\end{array}$ & $\begin{array}{l}3 \text { items and } \\
\text { one } \\
\text { dimensions } \\
\text { accounting } \\
\text { for } 76.42 \% \\
\text { of the total } \\
\text { variance }\end{array}$ & $\begin{array}{l}\text { One } \\
\text { dimension: } \\
\text { in the } \\
\text { range of } \\
\text { ".83" to } \\
\text { ".90". }\end{array}$ & $\begin{array}{l}\text { One } \\
\text { dimension: .84 }\end{array}$ \\
\hline $\begin{array}{l}\text { Organizational } \\
\text { Commitment }\end{array}$ & $\begin{array}{l}\text { Meyer and } \\
\text { Allen (1997), } \\
\text { Wasti (2000), } \\
\text { Başol and } \\
\text { Yalçın (2009) }\end{array}$ & $\begin{array}{l}\mathrm{KMO}= \\
.838, \\
\mathrm{p}=.000\end{array}$ & $\begin{array}{l}9 \text { items and } \\
\text { one } \\
\text { dimensions } \\
\text { accounting } \\
\text { for } 47.17 \% \\
\text { of the total } \\
\text { variance }\end{array}$ & $\begin{array}{l}\text { One } \\
\text { dimension: } \\
\text { in the } \\
\text { range of } \\
\text { ".49" to } \\
\text { “.81". }\end{array}$ & $\begin{array}{l}\text { One } \\
\text { dimension: .86 }\end{array}$ \\
\hline $\begin{array}{l}\text { Job } \\
\text { Satisfaction }\end{array}$ & $\begin{array}{l}\text { Hackman and } \\
\text { Oldham } \\
\text { (1975), } \\
\text { Basım and } \\
\text { Şeşen (2009), } \\
\text { Çetin'in } \\
\text { (2011) }\end{array}$ & $\begin{array}{l}\text { KMO = } \\
.799 \\
\mathrm{p}=.000\end{array}$ & $\begin{array}{l}5 \text { items and } \\
\text { one } \\
\text { dimensions } \\
\text { accounting } \\
\text { for } 64.32 \% \\
\text { of the total } \\
\text { variance }\end{array}$ & $\begin{array}{l}\text { One } \\
\text { dimension: } \\
\text { in the } \\
\text { range of } \\
\text { “.58” to } \\
\text { “.91". }\end{array}$ & $\begin{array}{l}\text { One } \\
\text { dimension: .85 }\end{array}$ \\
\hline Stress & $\begin{array}{l}\text { Karakuş } \\
\text { (2013) }\end{array}$ & $\begin{array}{l}\text { KMO = } \\
.749, \\
\mathrm{p}=.000\end{array}$ & $\begin{array}{l}4 \text { items and } \\
\text { one } \\
\text { dimensions }\end{array}$ & $\begin{array}{l}\text { One } \\
\text { dimension: } \\
\text { in the }\end{array}$ & $\begin{array}{l}\text { One } \\
\text { dimension: .83 }\end{array}$ \\
\hline
\end{tabular}




\begin{tabular}{|c|c|c|c|c|c|}
\hline & & & $\begin{array}{l}\text { accounting } \\
\text { for } 67.51 \% \\
\text { of the total } \\
\text { variance }\end{array}$ & $\begin{array}{l}\text { range of } \\
\text { “.80” to } \\
\text { “.85”, }\end{array}$ & \\
\hline $\begin{array}{l}\text { Individual } \\
\text { Performance }\end{array}$ & $\begin{array}{l}\text { Kirkman and } \\
\text { Rosen (1999), } \\
\text { Sulu (2010) }\end{array}$ & $\begin{array}{l}\mathrm{KMO}= \\
.793, \\
\mathrm{p}=.000\end{array}$ & $\begin{array}{l}4 \text { items and } \\
\text { one } \\
\text { dimensions } \\
\text { accounting } \\
\text { for } 65.82 \% \\
\text { of the total } \\
\text { variance }\end{array}$ & $\begin{array}{l}\text { One } \\
\text { dimension: } \\
\text { in the } \\
\text { range of } \\
\text { ".77” to } \\
\text { “.85". }\end{array}$ & $\begin{array}{l}\text { One } \\
\text { dimension: .83 }\end{array}$ \\
\hline Cynicism & $\begin{array}{l}\text { Vance, Brooks } \\
\text { and Tesluk } \\
\text { (1995), } \\
\text { Güzeller and } \\
\text { Kalağan } \\
\text { (2008) }\end{array}$ & $\begin{array}{l}\mathrm{KMO}= \\
.850 \\
\mathrm{p}=.000\end{array}$ & $\begin{array}{l}8 \text { items and } \\
\text { one } \\
\text { dimensions } \\
\text { accounting } \\
\text { for } 48.58 \% \\
\text { of the total } \\
\text { variance }\end{array}$ & $\begin{array}{l}\text { One } \\
\text { dimension: } \\
\text { in the } \\
\text { range of } \\
\text { ".62" to } \\
\text { ".79". }\end{array}$ & $\begin{array}{l}\text { One } \\
\text { dimension: .84 }\end{array}$ \\
\hline $\begin{array}{l}\text { Organizational } \\
\text { silence }\end{array}$ & $\begin{array}{l}\text { Dyne, Ang, } \\
\text { and Botero } \\
\text { (2003), } \\
\text { Briensfield } \\
\text { (2009), } \\
\text { Alparslan } \\
\text { (2010) }\end{array}$ & $\begin{array}{l}\mathrm{KMO}= \\
.693, \\
\mathrm{p}=.000\end{array}$ & $\begin{array}{l}3 \text { items and } \\
\text { one } \\
\text { dimensions } \\
\text { accounting } \\
\text { for } 74.87 \% \\
\text { of the total } \\
\text { variance }\end{array}$ & $\begin{array}{l}\text { One } \\
\text { dimension: } \\
\text { in the } \\
\text { range of } \\
\text { ".81" to } \\
\text { ".90". }\end{array}$ & $\begin{array}{l}\text { One } \\
\text { dimension: .83 }\end{array}$ \\
\hline $\begin{array}{l}\text { Individual- } \\
\text { Organization } \\
\text { Fit }\end{array}$ & $\begin{array}{l}\text { Aumann } \\
\text { (2007), } \\
\text { Vilela, } \\
\text { Gonzalez and } \\
\text { Ferrin (2008), } \\
\text { Piasentin } \\
\text { (2007), } \\
\text { Ulutaş, Kalkan } \\
\text { and Bozkurt } \\
\text { (2015) }\end{array}$ & $\begin{array}{l}\mathrm{KMO}= \\
.773 \\
\mathrm{p}=.000\end{array}$ & $\begin{array}{l}4 \text { items and } \\
\text { one } \\
\text { dimensions } \\
\text { accounting } \\
\text { for } 65.31 \% \\
\text { of the total } \\
\text { variance }\end{array}$ & $\begin{array}{l}\text { One } \\
\text { dimension: } \\
\text { in the } \\
\text { range of } \\
\text { ".74" to } \\
\text { ".86". }\end{array}$ & $\begin{array}{l}\text { One } \\
\text { dimension: .81 }\end{array}$ \\
\hline
\end{tabular}

The structure obtained as a result of the exploratory factor analysis was tested by the confirmatory factor analysis (Initial CFA), and if necessary, covariances among the appropriate items were identified (final CFA) and the final version of the model for the factor structure of the scales was defined. Detailed information about the fit values obtained from the confirmatory factor analysis is given in Table 2. 
Table 2. Confirmatory Factor Analysis (CFA) Fit Indices

\begin{tabular}{|c|c|c|c|c|c|c|c|c|c|c|}
\hline \multirow[b]{2}{*}{ Scales } & \multicolumn{10}{|c|}{ Model Fit Indices } \\
\hline & & $\mathrm{X}^{2}$ & sd & $\mathrm{X}^{2} / \mathrm{sd}$ & GFI & AGFI & NFI & CFI & RMSEA & SRMR \\
\hline \multirow{2}{*}{$\begin{array}{l}\text { Fit Value } \\
\text { Ranges }\end{array}$} & Acceptable & & & $0 / 5$ & $0,85 / 1$ & $0,8 / 1$ & $0,90 / 1$ & $0,90 / 1$ & $0,00 / 0,10$ & $0,00 / 0,08$ \\
\hline & $\begin{array}{l}\text { Good/Very } \\
\text { Good }\end{array}$ & & & $0 / 3$ & $0,95 / 1$ & $0,90 / 1$ & $0,95 / 1$ & $0,95 / 1$ & $0,00 / 0,05$ & $0,00 / 0,05$ \\
\hline \multirow{2}{*}{$\begin{array}{c}\text { Effectiveness } \\
\text { of School } \\
\text { Structure }\end{array}$} & Initial CFA & 202,54 & 53,00 & 3.80 & 0.90 & 0.86 & 0.94 & 0.96 & 0.09 & 0.03 \\
\hline & Final CFA & 145.89 & 52,00 & 2.80 & 0.94 & 0.90 & 0.96 & 0.97 & 0.07 & 0.03 \\
\hline \multirow{2}{*}{$\begin{array}{c}\text { Collective } \\
\text { efficacy }\end{array}$} & Initial CFA & 126.09 & 14,00 & 9.00 & 0.89 & 0.79 & 0.82 & 0.85 & 0.16 & 0.82 \\
\hline & Final CFA & 35.87 & 12,00 & 2.99 & 0.97 & 0.93 & 0.95 & 0.96 & 0.07 & 0.05 \\
\hline \multirow[t]{2}{*}{ Burnout } & Initial CFA & 82.48 & 14,00 & 5.90 & 0.92 & 0.86 & 0.96 & 0.96 & 0.12 & 0.35 \\
\hline & Final CFA & 37.41 & 13,00 & 2.88 & 0.97 & 0.94 & 0.98 & 0.99 & 0.07 & 0.02 \\
\hline \multirow{2}{*}{$\begin{array}{l}\text { Turnover } \\
\text { Intention }\end{array}$} & Initial CFA & - & - & - & 1,00 & - & 1,00 & 1,00 & 0.08 & 0,00 \\
\hline & Final CFA & & & & & & & & & \\
\hline \multirow[t]{2}{*}{ Interest in job } & Initial CFA & - & - & - & 1,00 & - & 1,00 & 1,00 & 0.07 & 0,00 \\
\hline & Final CFA & & & & & & & & & \\
\hline \multirow{2}{*}{$\begin{array}{l}\text { Organizational } \\
\text { Commitment }\end{array}$} & Initial CFA & 400.54 & 27,00 & 14.84 & 0.75 & 0.59 & 0.75 & 0.76 & 0.20 & 0.12 \\
\hline & Final CFA & 79.62 & 23,00 & 3.46 & 0.95 & 0.90 & 0.95 & 0.96 & 0.08 & 0.05 \\
\hline \multirow{2}{*}{$\begin{array}{c}\text { Job } \\
\text { Satisfaction }\end{array}$} & Initial CFA & 29.64 & 5,00 & 5.93 & 0.96 & 0.90 & 0.97 & 0.97 & 0.12 & 0.04 \\
\hline & Final CFA & 11.18 & 4,00 & 2.80 & 0.98 & 0.96 & 0.99 & 0.99 & 0.07 & 0.02 \\
\hline \multirow[t]{2}{*}{ Stress } & Initial CFA & 44.50 & 2,00 & 22.49 & 0.93 & 0.66 & 0.93 & 0.92 & 0.25 & 0.05 \\
\hline & Final CFA & 0.06 & 1,00 & 0.00 & 1,00 & 1,00 & 1,00 & 1,00 & 0,00 & 0,00 \\
\hline \multirow{2}{*}{$\begin{array}{c}\text { Individual } \\
\text { Performance }\end{array}$} & Initial CFA & 2.87 & 2,00 & 1.43 & 0.99 & 0.98 & 0.99 & 0.99 & 0.03 & 0.01 \\
\hline & Final CFA & - & - & - & - & - & - & - & - & - \\
\hline \multirow[t]{2}{*}{ Cynicism } & Initial CFA & 24.81 & 20,00 & 10.74 & 0.83 & 0.70 & 0.80 & 0.82 & 0.17 & 0.08 \\
\hline & Final CFA & 54.38 & 16,00 & 3.37 & 0.96 & 0.92 & 0.95 & 0.97 & 0.08 & 0.05 \\
\hline \multirow{2}{*}{$\begin{array}{c}\text { Organizational } \\
\text { silence }\end{array}$} & Initial CFA & - & - & - & 1,00 & - & 1,00 & 1,00 & 0.06 & 0,00 \\
\hline & Final CFA & & & & & & & & & \\
\hline \multirow{2}{*}{$\begin{array}{c}\text { Individual- } \\
\text { Organization } \\
\text { Fit }\end{array}$} & Initial CFA & 35.84 & 2,00 & 17.92 & 0.94 & 0.72 & 0.94 & 0.94 & 0.22 & 0.04 \\
\hline & Final CFA & 1.45 & 1,00 & 1.45 & 0.99 & 0.98 & 0.99 & 0.99 & 0.03 & 0.00 \\
\hline
\end{tabular}


The exploratory and confirmatory factor analyses that were conducted by establishing an item-factor relationship in line with the original structure of the scales, showed that that all scales had the same fit with the original factor structure. It was determined that the factor loads of the items of the scales were not below 0.40 .

\section{Data Analysis}

The necessary permissions were obtained from the rector's offices of the universities, which were included in the sample of the study, for performing the application to collect the data of the research. Following the applications for official permission made through the rector's office of Firat University, surveys were applied to academic staff at universities.

A regression analysis was performed to determine the predictability of other variables on individual performance and turnover intention, which was determined as a dependent variable. Regression analyses were conducted in two steps for the purpose of controlling the demographic variables, which were included in the model in the first step. Of these variables, variables such as gender, university status, and marital status, which are binary groups, were recoded as DUMMY variables. Accordingly, for the variable of age, 1: male, 0: female; for the variable of university status, 1 : state, 0 : foundation (private), and for the variable of marital status, 1: married, 0: single. Moreover, a path analysis was conducted in order to test the hypotheses of the research and identify the direct and indirect effects of the structure on other variables.

\section{FINDINGS}

As specified in the hypotheses of the research, the perceptions, attitudes and behaviours of the academics were addressed in two categories: positive and negative. Among these categories, individual performance was defined as a dependent variable, one of positive perceptions, based on the relevant literature and previous quantitative researches in line with the purpose of the study. Table 3 gives the findings of multiple hierarchical regression analysis indicating the predictive power of the perceptions, attitudes and behaviours of the academics participating in the research on the individual performance level. The analysis also examined the impact of demographic variables on individual performance.

Table 3. Findings of Regression Analysis on the Prediction of Individual Performance

\begin{tabular}{lllcccccc}
\multicolumn{8}{c}{ Performance } \\
\hline $\begin{array}{c}\text { Predictive } \\
\text { Variables }\end{array}$ & $\mathrm{R}$ & $\mathrm{R}^{2}$ & $\begin{array}{c}\mathrm{R}^{2} \\
\text { Adjusted } \\
\left(\Delta \mathrm{R}^{2}\right)\end{array}$ & $\mathrm{B}$ & $\begin{array}{c}\text { Standart } \\
\text { Error }\end{array}$ & $\beta$ & $\mathrm{t}$ & $\mathrm{P}$ \\
\hline Standart & & & & 1,999 &, 075 & & 26,705 &, 000 \\
\hline
\end{tabular}




\begin{tabular}{|c|c|c|c|c|c|c|c|c|}
\hline Step 1 & 064 & 004 & 000 & & & & & \\
\hline Age & & & &,- 003 & ,002 & $\begin{array}{c}- \\
, 050\end{array}$ & $-1,618$ & , 106 \\
\hline $\begin{array}{l}\text { Age of the } \\
\text { University }\end{array}$ & & & & ,000 & 001 & ,017 & ,585 & ,559 \\
\hline Gender & & & & 030 & ,035 & ,026 & 858 & 391 \\
\hline Marital Status & & & &,- 039 & ,041 & , 029 &,- 954 & ,340 \\
\hline $\begin{array}{l}\text { University } \\
\text { Status }\end{array}$ & & & & ,007 & ,041 & ,005 & 163 & ,871 \\
\hline Step 2 & ,419 & ,176 & ,168 & & & & & \\
\hline $\begin{array}{l}\text { Coercive } \\
\text { Structure }\end{array}$ & & & &,- 059 & ,026 & $\begin{array}{c}- \\
, 092\end{array}$ & $-2,292$ & ,022 \\
\hline $\begin{array}{l}\text { Enabling } \\
\text { Structure }\end{array}$ & & & & ,056 & ,027 & 091 & 2,039 & ,042 \\
\hline $\begin{array}{l}\text { Collective } \\
\text { Efficacy }\end{array}$ & & & & ,028 & ,038 & ,025 & 734 & 463 \\
\hline Interest in Job & & & & ,155 & ,027 & ,172 & 5,848 &, 000 \\
\hline $\begin{array}{l}\text { Organizational } \\
\text { Commitment }\end{array}$ & & & & ,064 & ,037 & ,049 & 1,753 & ,080 \\
\hline Job Satisfaction & & & & 296 & ,029 & 299 & 10,319 & 000 \\
\hline $\begin{array}{l}\text { Individual- } \\
\text { Organization Fit }\end{array}$ & & & & 067 & ,023 & , 100 & 2,919 & ,004 \\
\hline
\end{tabular}

Considering the data in Table 3, it is seen that the variables of gender, marital status, age, university status and university age (calculated taking into account the establishment date of university) included in the first step of the analysis are not significant predictors of individual performance $(\mathrm{R}=.064, \mathrm{R} 2=.004, \Delta . \mathrm{R} 2$ $=.000, \mathrm{p}>.05)$. The scores of the variables of coercive structure, enabling structure, collective efficacy, interest in job, organizational commitment, job satisfaction and individual-organization fit, that were included in the second step of the analysis, are significant predictors of individual performance $(\mathrm{R}=.419$, $\mathrm{R} 2$ $=.176, \Delta \mathrm{R} 2=.168, \mathrm{p}<.01)$. When the significance levels of the regression coefficients are examined separately, it is understood that the variables other than collective efficacy perception [coercive structure $(\beta=-.059, \mathrm{p}<.05)$, enabling structure $(\beta=.056, p<.05)$, interest in job $(\beta=.155, p<.01)$, job satisfaction $(\beta=$ .296, $\mathrm{p}<.01)$, individual-organization fit $(\beta=.067, \mathrm{p}<.05)]$ are significant predictors of individual performance scores. All independent variables of the research account for about 18\% (17.6) of the variance in the scores of individual performance scale. Around $17 \%$ of this is due to variables in the second step. Considering the standardized regression coefficients, the order of importance of predictor variables on individual performance is as follows: job satisfaction, 
interest in job, individual-organization fit, coercive structure, enabling structure and organizational commitment.

While testing the hypotheses, various paths were drawn by structural equation modelling for identifying the best hypothetical model for variables. For the purpose of reaching the best fit model, the following steps were followed: The trials of paths drawn should start with a model in which the relationship between the relevant variables is defined based on the conceptual framework. In each model trial, one of the paths having a partial mediating effect should be deleted, and its significance should be assessed taking into account the fit values. While performing these trials, the path trials with a significant contribution to the overall fit of the model should not be deleted, and only those with no contribution should be deleted (Bayram, 2010; Karakuş and Çankaya, 2012). It was seen that many path trials were required to be made to enable the analyses to continue within this framework and to find the best fit value. For these cases, all the paths that were drawn for the proposed model were selected from the "Specification Search" menu on the interface of the AMOS program. It was asked on the menu to identify all alternatives and propose the most suitable model, among the selected paths, taking into account the fit values which are important in the path analysis.

\section{Testing of Hypothesis 1}

The path analysis was performed to test the first hypothesis of the study (Coercive organizational structure has a negative effect directly and indirectly on academics' perception of individual performance) and to define the direct and indirect effects of the coercive structure on other variables. For this purpose, alternative paths for the effect of the coercive structure on positive perceptions were tried. The fit model that was determined accordingly is given in Figure 1.

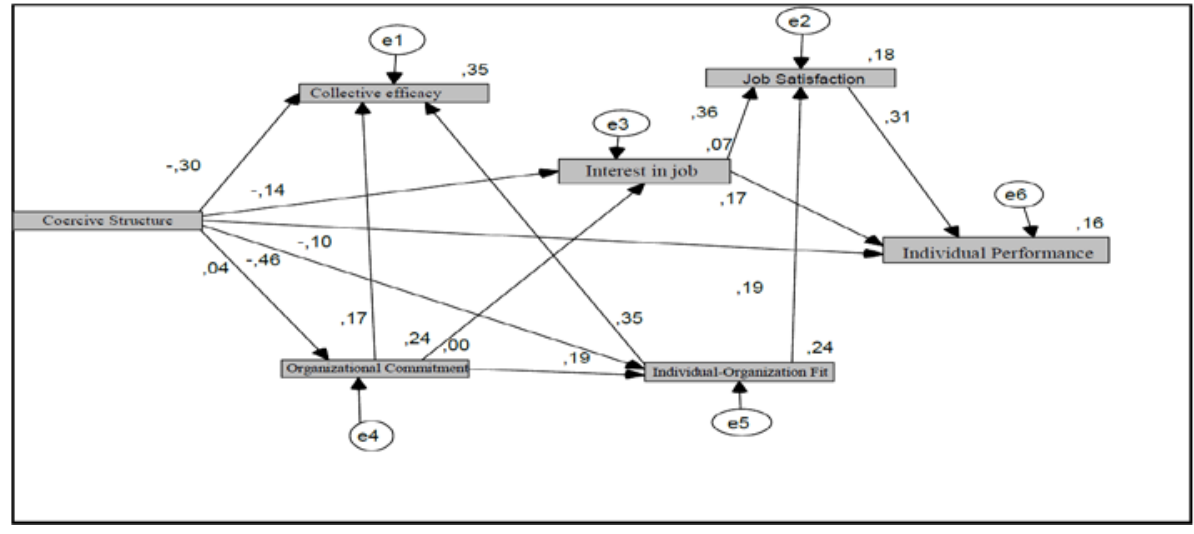

Figure 1. The Path Analysis Model Developed and Tested for Hypothesis 1 Chi-square: $16.65, \mathrm{df}=7$, Chi-square / $\mathrm{df}=2.379, \mathrm{p}=000, \mathrm{~N}=1242$ 
Table 4 shows the fit values of the model for path analysis of the variables considered within the scope of Hypothesis 1 of the research.

Table 4. Fit Values of the Path Analysis Model Developed and Tested for Hypothesis 1

\begin{tabular}{|c|c|c|c|c|c|c|c|c|c|}
\hline \multirow[t]{2}{*}{$\begin{array}{l}\text { Fit Values for the } \\
\text { Model }\end{array}$} & $\begin{array}{l}\text { Chi- } \\
\text { square }\end{array}$ & sd & $\begin{array}{l}\text { Chi- } \\
\text { square } \\
\text { /sd }\end{array}$ & CFI & GFI & AGFI & NFI & RMSEA & SRMR \\
\hline & 16.65 & 7 & 2.379 & .99 & .99 & .98 & .99 & .03 & .04 \\
\hline
\end{tabular}

According to Table 4, it is seen that the tested model has excellent fit values (Raykov, 1997, Sümer, 2000, Bayram, 2010). Except for the path drawn from the coercive structure to organizational commitment in the model, all paths were found to be statistically significant. There are overall, direct and indirect effects among the variables for the model that was developed and tested as the one having the best fit values among 152 alternatives offered by the program. According to these effects, the coercive structure does not significantly affect organizational commitment $(\beta=.36 ; \mathrm{t}=1.24 ; \mathrm{p}=0.213>0.05)$ in the model. Namely, it was not seen that a coercive university structure was influential on the academic staff in terms of organizational commitment. The coercive structure has a significant effect negatively and directly on individual-organization fit $(\beta=-.46$, $\mathrm{t}=-18.61, \mathrm{p}<0.001)$ and individual performance $(\beta=-.10, \mathrm{t}=-3.65, \mathrm{p}<0.001)$. This result shows that a coercive university structure negatively affects the individual performance of academic staff and their perception of fit with the university. Other variables directly affected by the coercive structure are interest in job $(\beta=-.14, \mathrm{t}=-4.98, \mathrm{p}<0.001)$ and collective efficacy $(\beta=-.30, \mathrm{t}=-11.455$, $\mathrm{p}<0.001)$. Considering the values of the direct and indirect effects of the coercive structure in the program, it is concluded that coercive structure has a negative effect on collective efficacy $(\beta=-.15, \quad \mathrm{p}<0.001)$ through organizational commitment and individual-organization fit. In other words, the perception of collective efficacy of academic staff is negatively affected by the coercive structure directly and indirectly. The coercive structure has a negative effect on job satisfaction $(\beta=-.1, \mathrm{p}<0.001)$ through organizational commitment and interest in job, and on individual performance $(\beta=-.06, p<0.001)$ through interest in job and job satisfaction. Individual performance, which is a dependent variable, is negatively affected by the coercive structure directly and indirectly. In other words, a coercive university structure negatively affects the individual performance of academic staff in every sense. Along with these results, organizational commitment has a positive effect directly on interest in job ( $\beta=$ $.23, \mathrm{t}=8.76, \mathrm{p}<0.001)$, individual-organization fit $(\beta=.19, \mathrm{t}=7.69, \mathrm{p}<0.001)$ and collective efficacy $(\beta=.17, \mathrm{t}=7.43, \mathrm{p}<0.001)$. Individual-organizational fit has a 
positive effect directly on collective efficacy $(\beta=.34, \mathrm{t}=13.18, \mathrm{p}<0.001)$ and job satisfaction $(\beta=.19, \mathrm{t}=7.30, \mathrm{p}<0.001)$. While job satisfaction has a positive effect directly on individual performance $(\beta=.31, \mathrm{t}=10.98, \mathrm{p}<0.001)$, interest in job has a positive affect directly on job satisfaction $(\beta=.35, \mathrm{t}=13.54, \mathrm{p}<0.001)$ and individual performance $(\beta=.16, \mathrm{t}=5.85, \mathrm{p}<0.001)$.

As can be seen in the path analysis, the coercive structure, which forms the negative dimension of the organizational structure, usually has a negative impact on positive perceptions. The coercive structure, whether directly or indirectly, has a negative effect on the positive perceptions of academics. This result means that Hypothesis 1 (Coercive organizational structure has a negative effect directly and indirectly on academics' perception of individual performance) is accepted. In this model, it was understood that variables in the model that had an effect on individual performance accounted for about $16 \%$ of the change in individual performance. The dependent variable affected by all variables in the model is individual performance.

\section{Testing of Hypothesis 2}

The path analysis was performed to test the second hypothesis of the study (Enabling organizational structure has a positive effect directly and indirectly on academics' perception of individual performance) and to define the direct and indirect effects of the enabling structure on other variables. For this purpose, alternative paths for the effect of the enabling structure on positive behaviours were tried. The fit model that was determined accordingly is given in Figure 2.

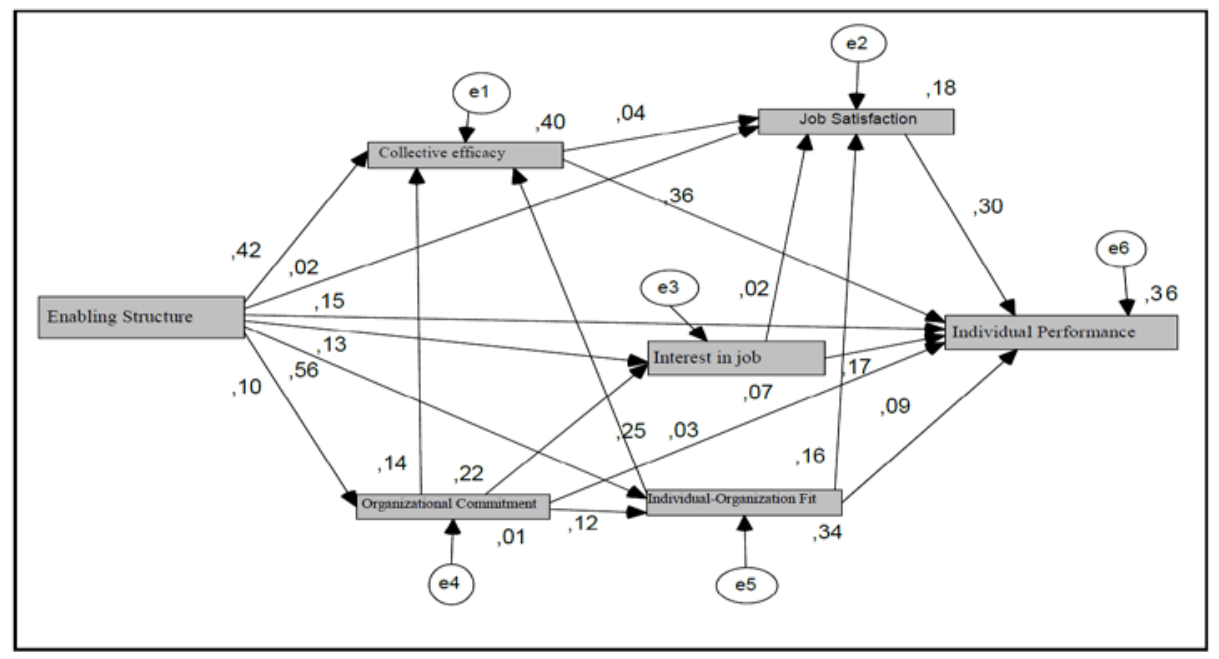

Figure 2. The Path Analysis Model Developed and Tested for Hypothesis 2

Chi-square: 5,368, sd=2, Chi-square/sd=2.684, $\mathrm{p}=000, \mathrm{~N}=1242$ 
The model in Figure 2 examines the explanatory and predictive relationships between variables using the maximum likelihood technique in Structural Equation Modelling. Accordingly, none of the paths in the proposed model was removed from the model by the program, and the path analysis continued in this way, because it had good fit values. Table 5 shows the fit value for the model of Hypothesis 2.

Table 5. Fit Values of the Path Analysis Model Developed and Tested for Hypothesis 2

\begin{tabular}{|c|c|c|c|c|c|c|c|c|c|}
\hline \multirow{2}{*}{$\begin{array}{l}\text { Fit Values for } \\
\text { the Model }\end{array}$} & $\begin{array}{l}\text { Chi- } \\
\text { square }\end{array}$ & sd & $\begin{array}{l}\text { Chi- } \\
\text { square/sd }\end{array}$ & CFI & GFI & AGFI & NFI & RMSEA & SRMR \\
\hline & 5.368 & 2 & 2.684 & .99 & .99 & .98 & .99 & .04 & .01 \\
\hline
\end{tabular}

According to Table 5, it is seen that the tested model has excellent fit values (Raykov, 1997, Sümer, 2000, Bayram, 2010). In the model, all paths were found to be statistically significant. There are overall, direct and indirect effects among the variables for the model that was developed and tested as the one having the best fit values among 162 alternatives offered by the program. According to these effects, the enabling structure has a significant positive effect directly on organizational commitment $(\beta=.10, \mathrm{t}=3.665, \mathrm{p}<0.001)$. Enabling structure has positive effect directly on individual-organization fit $(\beta=.56, \mathrm{t}=23.999, \mathrm{p}$ $<0.001)$, interest in job $(\beta=.013, \mathrm{t}=4.864, \mathrm{p}<0.001)$, collective efficacy $(\beta=.42$, $\mathrm{t}=15.65, \mathrm{p}<0.001)$ and job satisfaction $(\beta=.017, \mathrm{t}=.494, \mathrm{p}<0.001)$ This result shows that enabling structure has a positive effect on the positive behaviours of academic staff. Enabling structure affects the individual performance $(\beta=.15$, $\mathrm{t}=4.233, \mathrm{p}<0.001$ ) directly and positively. Moreover, enabling structure has a positive effect on the individual performance also through individualorganization fit $(\beta=.012, p<0.001)$, collective efficacy $(\beta=.16, p<0.001)$, interest in job $(\beta=.023, \mathrm{p}<0.001)$ and job satisfaction $(\beta=.170, \mathrm{p}<0.001)$. Individual performance, which is the dependent variable of the model, is positively affected by the enabling structure directly and indirectly. This result reveals that the enabling structure in universities positively affects the performance of academic staff, and it is important for the climate of universities and behaviours of academics. This result demonstrates that Hypothesis 2 is accepted. In this model, it was understood that variables in the model that had an effect on individual performance accounted for about $36 \%$ of the change in individual performance.

As specified in the hypotheses of the research, the behaviours of the academics were addressed in two categories: positive and negative. In accordance with the purpose of the research, the turnover intention, among these categories, was 
defined as the dependent variable based on literature and previous studies. Table 7 gives the findings of multiple hierarchical regression analysis indicating the predictive power of the perceptions, attitudes and behaviours of the academics participating in the research on their turnover intention. The analysis also examined the impact of demographic variables on the turnover intention.

Table 6. Findings of Regression Analysis on the Prediction of the Academics' Turnover Intention

\begin{tabular}{|c|c|c|c|c|c|c|c|c|}
\hline $\begin{array}{l}\text { Predictive } \\
\text { Variables }\end{array}$ & $\mathrm{R}$ & $\mathrm{R}^{2}$ & $\begin{array}{c}\mathrm{R}^{2} \\
\text { Adjusted } \\
\left(\Delta \mathrm{R}^{2}\right)\end{array}$ & B & $\begin{array}{l}\text { Standart } \\
\text { Error }\end{array}$ & $\beta$ & $\mathrm{t}$ & $\mathrm{P}$ \\
\hline Standart & & & & 3,470 & ,139 & & 24,914 &, 000 \\
\hline Step 1 & ,183 & ,034 & ,030 & & & & & \\
\hline Age & & & & ,001 & ,003 & ,010 & ,327 & ,744 \\
\hline $\begin{array}{l}\text { Age of the } \\
\text { University }\end{array}$ & & & & ,001 & ,001 & ,022 & ,767 & ,443 \\
\hline Gender & & & & ,235 & ,065 & ,107 & 3,613 &, 000 \\
\hline Marital Status & & & & ,194 & ,077 &, 076 & 2,520 &, 012 \\
\hline $\begin{array}{l}\text { University } \\
\text { Status }\end{array}$ & & & & ,279 & ,076 & , 105 & 3,655 &, 000 \\
\hline Step 2 & ,703 & ,494 & ,490 & & & & & \\
\hline $\begin{array}{l}\text { Coercive } \\
\text { Structure }\end{array}$ & & & & 310 & ,039 & ,021 & 643 & ,520 \\
\hline $\begin{array}{l}\text { Enabling } \\
\text { Structure }\end{array}$ & & & &,- 270 & ,037 & $\begin{array}{c}- \\
125\end{array}$ & $-3,958$ & ,000 \\
\hline Burnout & & & & ,683 & ,036 & ,533 & 17,385 & ,000 \\
\hline Stress & & & & ,570 & ,035 & , 180 & 6,010 & ,000 \\
\hline Cynicism & & & & ,065 & ,059 & ,050 & 2,298 & ,022 \\
\hline $\begin{array}{l}\text { Organizational } \\
\text { silence }\end{array}$ & & & & ,264 & ,027 & ,035 & 1,541 & ,124 \\
\hline
\end{tabular}

Considering the data in Table 6, it is seen that the demographic variables such as gender, marital status, age, university status and university age included in the first step of the analysis are significant predictors of the turnover intention $(\mathrm{R}=.18, \mathrm{R} 2=.03, \Delta \mathrm{R} 2=.03, \mathrm{p}<.01)$. When the significance levels of regression coefficients are examined together with this result, it is understood that the variables of gender $(\beta=.23, \mathrm{p}<.01)$, marital status $(\beta=.19, \mathrm{p}<.01)$, and university 
status $(\beta=.27, \mathrm{p}<.01)$ are significant predictors of the scores of turnover intention. It is revealed that the variables of coercive structure, enabling structure, burnout, stress, cynicism and silence, included in the second step of analysis, have a significant effect on the scores of turnover intention $(\mathrm{R}=.70, \mathrm{R} 2=.49, \mathrm{R} 2=$ $.49, \mathrm{p}<.01$ ). Besides, when the significance levels of the regression coefficients are examined separately, it is understood that the variables of enabling structure $(\beta=-, 27, p<.05)$, burnout $(\beta=.68, p<.01)$, stress $(\beta=.57, p<.01)$, and cynicism $(\beta=.06, p<.0)$ are significant predictors of the scores of turnover intention. Despite these results, it was concluded that the coercive structure $(\beta=.15, \mathrm{p}>.01)$ and silence $(\beta=.15, \mathrm{p}>.01)$ had no significant effect on the turnover intention. Namely, it is seen that the enabling structure has generally a negative effect on the negative behaviours of academic staff, while the coercive structure does not have any significant effect. All independent variables of the research account for $49 \%$ of the variance in the scores of turnover intention. Around $44 \%$ of this is due to variables in the second step.

\section{Testing of Hypothesis 3}

The path analysis was performed to test the third hypothesis of the study (Coercive organizational structure has a positive effect directly and indirectly on academics' perception of turnover intention) and to define the direct and indirect effects of the coercive structure on the turnover intention. For this purpose, alternative paths for the effect of the coercive structure on negative behaviours were tried. The fit model that was determined accordingly is given in Figure 3.

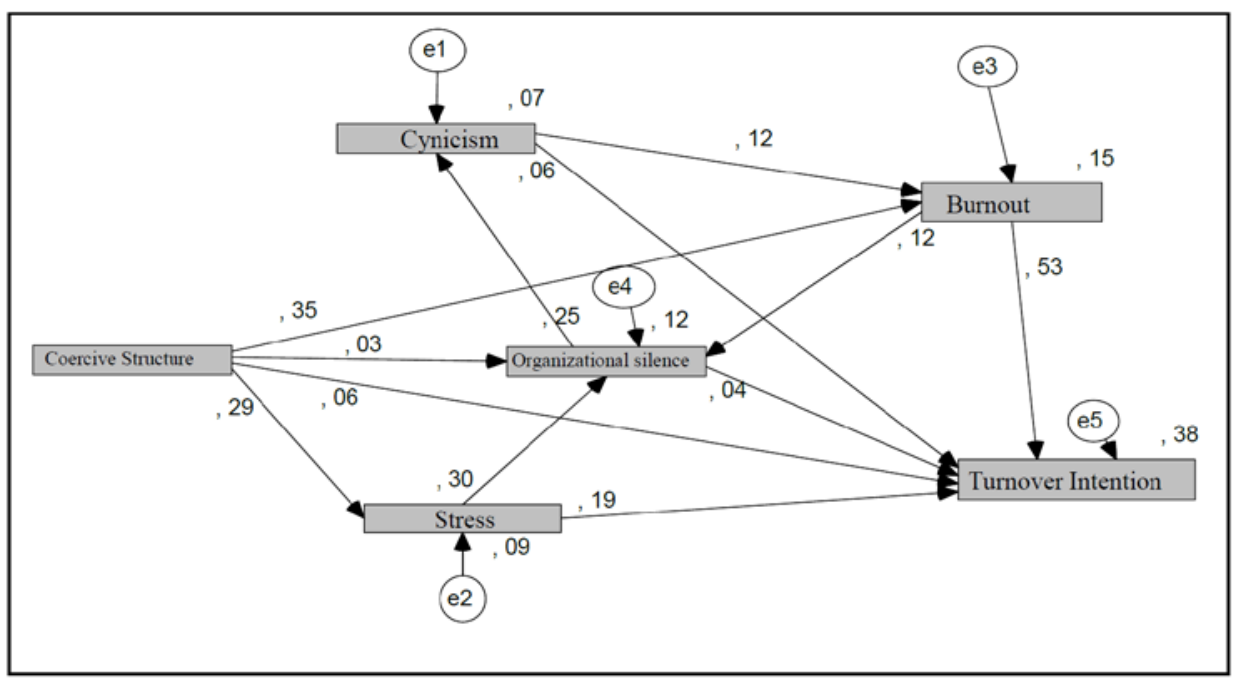

Figure 3. The Path Analysis Model Developed and Tested for Hypothesis 3

Chi-square: 1,490 sd=2, Chi-square/sd=,745, $\mathrm{p}=000, \mathrm{~N}=1242$ 
The model, which was developed based on the relevant literature and researches in the field, was tested by using path analysis that is one of the structural equation models. Using the maximum likelihood technique in Structural Equation Modelling, the explanatory and predictive relationships between variables in the model were examined. Therefore, the path from the coercive structure to cynicism and the paths from stress to burnout were removed from the model proposed for Hypothesis 3 by taking into account their fit values. Table 7 shows the fit value of the model for the path analysis of the research.

Table 7. Fit Values of the Path Analysis Model Developed and Tested for Hypothesis 3

\begin{tabular}{|c|c|c|c|c|c|c|c|c|c|}
\hline \multirow{2}{*}{$\begin{array}{l}\text { Fit Values for } \\
\text { the Model }\end{array}$} & $\begin{array}{l}\text { Chi- } \\
\text { square }\end{array}$ & sd & $\begin{array}{l}\text { Chi- } \\
\text { square/sd }\end{array}$ & CFI & GFI & AGFI & NFI & RMSEA & SRMR \\
\hline & 1.490 & 2 & .745 & .99 & .99 & .98 & .99 & .001 & .01 \\
\hline
\end{tabular}

According to Table 7, it is seen that the tested model has excellent fit values (Raykov, 1997, Sümer, 2000, Bayram, 2010). In the model, all paths were found to be statistically significant. There are overall, direct and indirect effects among the variables for the model that was developed and tested as the one having the best fit values among 122 alternatives offered by the program. According to these effects, the coercive structure in the model has a positive effect directly on stress $(\beta=.29, \mathrm{t}=10.782, \mathrm{p}<0.001)$, turnover intention $(\beta=.06, \mathrm{t}=10.781, \mathrm{p}<0.001)$, burnout $(\beta=.35, \mathrm{t}=10.781, \mathrm{p}<0.001)$ and silence $(\beta=.03, \mathrm{t}=10.781, \mathrm{p}<0.001)$. Namely, as the organizational structure in universities reflects the characteristics of the coercive structure, the level of negative perceptions, attitudes and behaviours of academic staff also increases. The coercive structure also has a positive effect indirectly on burnout through silence $(\beta=.12, p<0.001)$ and cynicism $(\beta=.03, \mathrm{p}<0.001)$. The turnout intention is directly affected by the coercive structure, and it is also affected positively and indirectly by it through stress, silence and burnout. Moreover, the turnout intention is affected directly and positively by cynicism $(\beta=.06, p<0.001)$, stress $(\beta=.19, \mathrm{p}<0.001)$, silence $(\beta=.04, \mathrm{p}<0.001)$, and burnout $(\beta=.53, \mathrm{p}<0.001)$. These results show that the coercive structure that exists in universities has an effect on the turnover intention of academic staff.

As can be seen in the path analysis, the coercive structure, which forms the negative dimension of the organizational structure, usually has a positive impact on negative behaviours. This means that Hypothesis 3 (Coercive organizational structure has a positive effect on the academics' perception of turnover intention, cynicism, stress, silence and burnout) is accepted. It is understood that variables 
in this model account for around 38\% of the variance in the turnover intention. The dependent variable affected by all variables in the model is the turnover intention.

\section{Testing of Hypothesis 4}

The path analysis was performed to test the fourth hypothesis of the study (Enabling organizational structure has a negative effect directly and indirectly on academics' perception of turnover intention) and to define the direct and indirect effects of the enabling structure on the turnover intention. For this purpose, alternative paths for the effect of the enabling structure on negative behaviours were tried. The fit model that was determined accordingly is given in Figure 4.

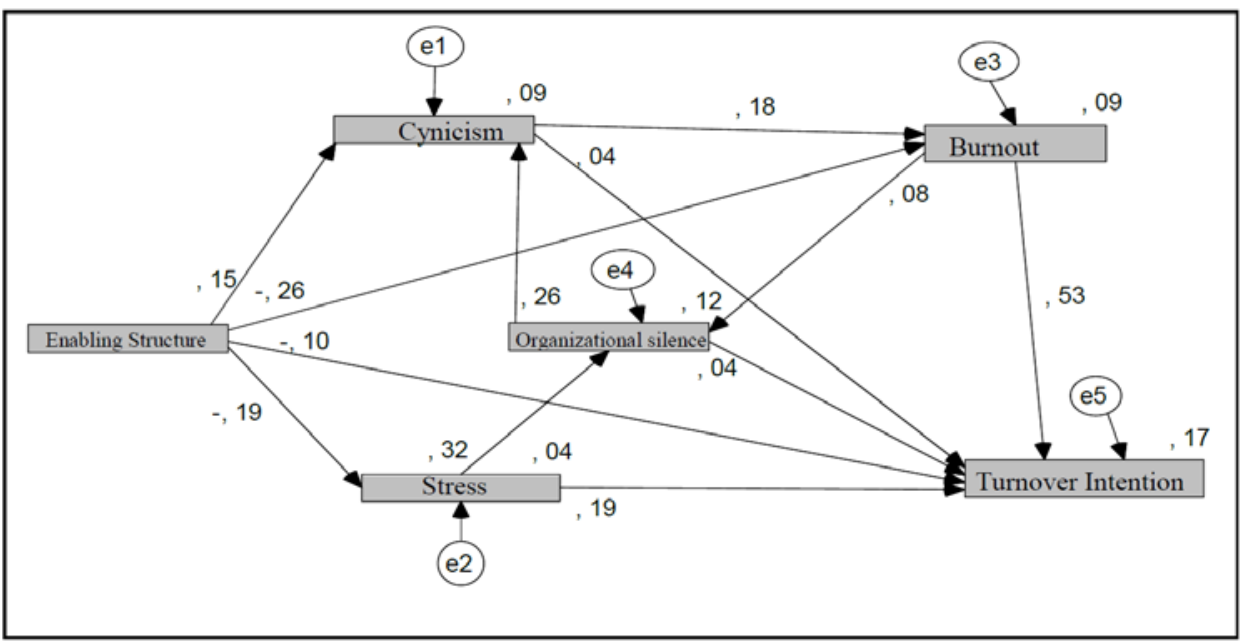

Figure 4. The Path Analysis Model Developed and Tested for Hypothesis 4

Chi-square: 12,231 , sd=3, Chi-square/sd=4,077, $\mathrm{p}=000, \mathrm{~N}=1242$

The model, which was developed based on the relevant literature and researches in the field, was tested by using path analysis that is one of the structural equation models. Using the maximum likelihood technique in Structural Equation Modelling, the explanatory and predictive relationships between variables in the model were examined. Therefore, the path from the enabling structure to silence and the paths from stress to burnout were removed from the model proposed for Hypothesis 4 by taking into account their fit values. Table 8 shows the fit value of the model for the path analysis of the research. 
Table 8. Fit Values of the Path Analysis Model Developed and Tested for Hypothesis 4

\begin{tabular}{llllllllll}
\hline \multirow{2}{*}{\begin{tabular}{c} 
Fit Values for $\begin{array}{l}\text { Chi- } \\
\text { the Model }\end{array}$ \\
\cline { 2 - 9 }
\end{tabular}} & \begin{tabular}{l} 
square \\
\cline { 2 - 9 }
\end{tabular} & sd & $\begin{array}{l}\text { Chi- } \\
\text { square/sd }\end{array}$ & CFI & GFI & AGFI & NFI & RMSEA & SRMR \\
\hline
\end{tabular}

According to Table 8, it is seen that the tested model has excellent fit values (Raykov, 1997, Sümer, 2000, Bayram, 2010). In the model, all paths were found to be statistically significant. There are overall, direct and indirect effects among the variables for the model that was developed and tested as the one having the best fit values among 122 alternatives offered by the program. According to these effects, the enabling structure in the model has a negative effect directly on stress $(\beta=-0.19, \mathrm{t}=-6.819, \mathrm{p}<0.001)$, burnout $(\beta=-0.26, \mathrm{t}=-9.260, \mathrm{p}<0.001)$, cynicism $(\beta=0,15, \mathrm{t}=5.444, \mathrm{p}<0.001)$ and the turnover intention $(\beta=-0.10, \mathrm{t}=-6.216, \mathrm{p}$ $<0.001$ ). Namely, the enabling structure of the organization in universities affects negatively the academic staff's perceptions of negative behaviours. Therefore, in the universities having an enabling organizational structure, especially academic staff may be expected to have no or low turnover intention. The enabling structure also has a negative effect indirectly on the turnover intention through stress, burnout and cynicism. The turnover intention is directly and positively affected by cynicism $(\beta=0.04, \mathrm{t}=4,024, \mathrm{p}<0.001)$, stress $(\beta=0.19, \mathrm{t}=21,332, \mathrm{p}<0.001)$, silence $(\beta=0.04, \mathrm{t}=2,459, \mathrm{p}<0.001)$ and burnout $(\beta=0.53, \mathrm{t}=4,134, \mathrm{p}<0.001)$. While the coercive structure affects silence both directly and through stress and burnout, the enabling structure does not have a direct effect on silence. Based on this result, it is concluded that the coercive structure increases silence in universities, but the enabling structure does not have any effect on preventing silence. In other words, it is necessary but not enough to have an enabling structure to prevent the silence of academic staff in universities.

As can be seen in the path analysis, the enabling structure, which forms the positive dimension of the organizational structure, usually has a negative impact on negative behaviours. This means that Hypothesis 4 (Enabling organizational structure has a negative effect on the academics' perception of turnover intention, cynicism, stress, silence and burnout) is accepted. It is understood that variables in this model account for around $17 \%$ of the variance in the turnover intention. The dependent variable affected by all variables in the model is the turnover intention. 


\section{Results and Discussion}

Many criteria are required to be observed to evaluate academics' perceptions of organizational structure. The relationship between some variables, among these criteria, that were determined in the light of the studies in the literature, and the academics' perceptions of organizational structure was addressed in this study. Particularly, to what extent and how the organizational structure affects the individual performance, which can be considered as one of the positive variables of the academics, and the turnover intention, which can be considered as one of the negative variables, was examined in this study. Besides, the relationship between academics' perceptions of collective efficacy, individualorganization fit, job satisfaction, organizational commitment, burnout, stress, interest in job, and cynicism, and the organizational structure was also addressed for the purpose of this study, and the hypothetical models based on the hypotheses for this relationship were proposed.

The results and discussions based on the research findings are given in this part. With the data obtained and the analysis of hypotheses 1 and 2, the following results were reached. According to the results of regression analysis, it was concluded that the variables of coercive structure, enabling structure, collective efficacy, interest in job, organizational commitment, job satisfaction and individual-organization fit are significant predictors of the scores of individual performance. While the coercive structure predicts the variable of individual performance perception in a negative way, the interest in job, job satisfaction and individual-organization fit predict it positively. All independent variables of the research account for about $17 \%$ of the variance in the scores of individual performance scale. The research by Aypay (2006) on the relationship between academic activity and organizational behaviour points out that there is a partial relationship between organizational models and academics' activities. This study also reveals that there is a high level of positive relationship between these organizational models. The model that was developed in line with the literature to define the relationships between the variables within the scope of the study was tested using the path analysis, that is one of the structural equation models. As a result, in the best fit model, it was concluded that the coercive structure negatively and directly affected the individual-organization fit, individual performance, interest in job and collective efficacy. At the same time, the coercive structure affects the collective efficacy negatively through the organizational commitment and individual-organization fit; it affects job satisfaction negatively through organizational commitment and interest in job, and it has also a negative effect on the individual performance through organizational commitment, interest in job and job satisfaction. In this model, it was concluded that the observed variables accounted for $16 \%$ of the change in individual performance. 
Academics' perceptions of the enabling structure positively and directly affect the organizational commitment, individual-organization fit interest in job, collective efficacy and job satisfaction. In other words, the fact that the organizational structure shows enabling characteristics has positive effects on important variables in terms of the effectiveness and efficiency of universities. In addition, it is concluded that the enabling structure in universities positively affects the individual performance. Based on the findings of the research, it can be suggested that the coercive organizational structure of universities negatively affects both the performance and the emotions, attitudes and behaviours of academics that affect their performance. On the other hand, the universities having an enabling structure positively affect the same feelings, attitudes and behaviours. Ardıç and Polat (2008) performed a study in which they intended to define the burnout levels of academic staff, and the relationship between their burnout level and some variables, and finally to offer solutions and suggestions for the burnout problem of academic staff. According to the research findings, in order to prevent high burnout among the academic staff in terms of individual success, it is necessary to allow personal development, and the feelings of burnout by academic staff may decrease when the necessary measures are taken.

With the data obtained and the analysis of hypotheses 3 and 4, the following results were reached. According to the results of regression analysis, it was determined that the variables of enabling structure, burnout, stress and cynicism were a significant predictor of the scores of turnout intention. All independent variables of the research account for $49 \%$ of the variance in the scores of turnover intention scale. Around $44 \%$ of this is due to the variables of burnout, stress and cynicism combined with the coercive structure in the second step. Sabuncuoglu (2007) examined how organizational commitment, turnover intention, and education can be related. The model established by path analysis method was tested. Almost all variables of education were found to affect the turnover intention directly and indirectly through organizational commitment. An important point is that direct effects are lower than indirect effects. The study conducted in 2015 by Zeynel and Çarıkçı attempted to determine the relationship between the professional motivations of academic staff and their perceptions of job satisfaction and organizational commitment. As a result of the analysis conducted in the study, it was concluded that with the increase in the level of professional motivation of academic staff, their job satisfaction and organizational commitment would also increase positively and significantly.

According to the results of the path analysis, the coercive structure directly and positively affects stress, silence, burnout and turnover intention. The coercive structure also indirectly and positively affects the turnover intention through burnout, stress, and silence. It was concluded that the variables observed in the model accounted for around $38 \%$ of the variance in the turnover intention. In 
other words, the coercive characteristics of the organizational structure in universities increase the level of burnout, stress and silence of academics and their turnover intention.

In the path analysis performed to define the effects of the enabling structure on stress, burnout, cynicism and turnover intention, it was concluded that the enabling structure directly and negatively affected the scores of these variables. The enabling structure also has a negative effect indirectly on the turnover intention through stress, burnout and cynicism. It was determined that the observed variables in the model accounted for around $17 \%$ of the variance in the turnover intention.

It is seen that the results of regression and path analysis are mostly parallel to each other. Accordingly, the fact that the organizational structure of universities shows coercive characteristics increases academics' stress, burnout, cynicism levels and turnover intention. On the contrary, the perception of the organizational structure of universities as an enabling structure reduces academicians' stress, burnout and cynicism levels, and their turnover intention. A striking result from this study is that the coercive structure in universities is more effective than the enabling structure on the academics' negative feelings and attitudes such as stress, burnout and cynicism. Namely, while the coercive structure increases the negative feelings and attitudes in the organizational environment, the enabling structure has a lower level of reducing effect on these variables. Based on this result, it is necessary, but not enough, for the organizational structure of universities to show enabling characteristics in order to reduce the negative emotions and attitudes of academics such as stress, burnout and cynicism. In another study, despite not at the university level, Smith and Meier (1994) noted that the bureaucratic structure could have positive effects on the management of educational institutions. According to the authors, bureaucratic structure does not cause a decline in performance. On the contrary, they suggest that the reduced bureaucracy in educational institutions has led to reduced performance.

According to academics' perceptions, the fact that universities show coercive characteristics in terms of their organizational structure increases the academics' cynicism, stress, silence, burnout, and their turnover intention related to them. For this reason, in order to reduce negative emotions and attitudes in universities, it is necessary to eliminate the features of the organizational structure that are perceived as coercive and to provide a more enabling structure. In terms of the variables discussed in this study, the fact that the administrative structure in universities is enabling is as important as the leadership behaviours of the directors that operate this system and make decisions on it. Based on this point, upper, middle and lower level directors in universities should display supporting 
and enabling leadership behaviours. For this reason, various measures can be taken in order to improve the leadership skills of the persons that have managerial positions in universities. It is highly important to take into account the leadership skills particularly in the appointment of rectors, deans and directors. A university structure that has intense paperwork, departmentalization and hierarchy, which are among the negative characteristics of the coercive organizational structure, may lead to negative outcomes for academics who work under time pressure. With the help of technology, paperwork should be minimized, and it should be tried to create a flexible organizational structure.

\section{REFERENCES}

Adler, P. and Borys, B. (1996). Two types of bureaucracy: enabling and coercive. Administrative Science Quarterly, 41, 61-89.

Allen, N. J. and Meyer, J. P., (1996). Affective, continuance, and normative commitment to the organization: An examination of construct validity. Journal of Vocational Behavior, 49, 252-276.

Alparslan, A.M. (2010). The interaction between organizational silence climate and employee silence behaviors: a research on mehmet akif ersoy university faculty members. [Unpublished Master Thesis]. Süleymen Demirel University.

Altıntaş, E. (2003). Stress management. Alfa Publications.

Antalyalı, L. Ö. (2008). Areas of Turkey university organizational effectiveness: a research on teaching. [Unpublished Doctorate Thesis]. Süleyman Demirel University.

Astin, A. W., and Scherrei, R. (1984). Maximizing leadership effectiveness. Jossey-Bass.

Aumann, K. A. (2007). Being a stranger in a strange land: the relationship between person-organizastion fit on work related and broad cultural value dimensions and outcomes related to expatriastes' success, Columbia University, PreQuest Information and Learning Company

Avc1, N. (2008). Analysis of the relationship between organizational learning, business attitudes and organizational deviation in hospitality business. [Unpublished Doctorate] Dokuz Eylül University.

Aypay, A. (2001). The relationship between organizational structures and faculty roles at colleges and universities (Unpublished Doctoral Dissertation). Vanderbillt University: Nashville, TN, USA. 
Aypay, A. (2003). The relationship between State and higher education: The case of Mulkiye college in Turkey. Mediterranean Journal of Educational Studies. 8(2), 109-135.

Aypay, A. (2006). The relationship between academic activity and organizational behavior in universities. Educational Administration: Theory and Practice,12(2), 175-198.

Bailey, K. (1994). Methods of social research (4th Ed.). NY: The Free Press.

Balc1, A. (2003). Organizational socialization theory, strategy and tactics. Pegem Publishing.

Bandura, A. (1997). Self-Efficacy: The Exercise Of Control. W. H.Freeman And Company.

Basım, H.N., and Şeşen, H. (2009). The mediating role of job satisfaction in the relationship between perception of organizational justice and organizational citizenship behavior, 17. Management and Organization Congress Proceedings, Eskişehir, 21-23 May.

Başol, G., and Yalçın, B. (2009). The validity and reliability study of Meyer and Allen Three Dimensional Organizational Commitment Scale in educational organizations. International Balkan Educational and Science Congress Full Text Book, 2, 497- 507

Bayram, N. (2010). Introduction to structural equation modeling. Ezgi Publishing House.

Bergquist, W. H. (1992). The four cultures of the academy. Jossey Bass.

Bess, J.L. (1984). College and university organization: insights from the behavioral sciences. NYU Press.

Bhuian, S. N., Menguc, B., and Borsboom, R. (2005). Stressors and job outcomes in sales: A triphasic model versus a linear-quadratic-interactive model. Journal of Business Research, 58(2), 141-150.

Birnbaum, R. (1988). How colleges work: the cybernetics of academic organization. Jossey Bass.

Blau, P. M. (1973). The organization of academic work. John Wiley and Sons.

Breukelen J.W.M. Van. (1988). Job turnover: a review and a model (İn Dutch). Gedrag \& Organisati E 1 (6), 37-65. 
Brinsfield, C., T. (2009). Employee Silence: Investigation of Dimensionality, Development of Measures, and Examination of Related Factors, Dissertation, Ohio State University, USA.

Buluç, B. (2009). The Relationship Between Bureaucratic School Structure and Leadership Styles of School Principals in Primary Schools. Education and Science, 34(152), 71-86.

Cerit, Y. (2013). The Relationship Between Bureaucratic Structure of School and Professional Behaviors of Classroom Teachers. Educational Administration in Theory and Practice, 18(4), 497-521.

Childers, M. E. (1981). What is political about bureaucratic-collegial decision making? Review of Education, 5(1), 25-45.

Christensen, L. B., Johnson, B., and Turner, L. A. (2015). Research methods, design, and analysis.(Çev. A.Aypay). Anı Publishing.

Cochran, W. G. (1977). Sampling techniques (3rd ed.), John Wiley\& Sons.

Cole, J. C., Rabin, A. S., Smith, T. L., and Kaufman, A. S. (2004). Development and validation of a Rasch-derived CES-D short form. Psychological assessment, 16(4), 360.

Cüceloğlu, D. (1994). Human and behavior. basic concepts of psychology. Remzi Bookstore.

Çakır, Ö. (2001). Work Commitment and Affecting Factors. Seçkin Publishing.

Çetin, F. (2011). The role of organizational commitment, job satisfaction, personality and organizational culture in explaining organizational citizenship behaviors. [Unpublished Doctorate Thesis]. Ankara University.

Daft, R. L. and Marcic, D. (2009). Understandingmanagement (6th ed.). Mason, $\mathrm{OH}$ : South-Western College.

Deal, T.E., and Bolman, L.G. (1987). Reframing Organizations, SanFrancisco: Jossey Bass.

Dean, J. W., Brandes, P. and Rahi, D. (1998). Organizational cyncism. The Academy of Management Review, 23(2), 341-352.

Donders J. A. (1997). Short form of the WISC-III for clinical use. Psychol Assess, 9: 15-20. 
Dyne, L. V., Ang, S., and Botero, I. C. (2003). Conceptualizing employee silence and employee voice as multidimensional constructs. Journal of management studies, 40(6), 1359-1392.

Ergin, C. (1992). Application of burnout and Maslach burnout inventory in doctors and nurses. Scientific Studies of the 7th National Psychology Congress, Ankara.

Goddard, R. D., Hoy, W K. and Hoy, A. W (2004). Collective efficacy: theoretical development, empirical evidence, and future directions. Educational Researcher, 33 (3), 3-13.

Güven, O. (2002). A study to examine and analyze the effects of organizational attitudes on employee behavior. [Unpublished Doctorate Thesis]. Istanbul University.

Hoy, W. K. (2003). An analysis of enabling and mindful school structures. some theoretical, research and practical considerations. Journal Of Educational Adrninistration, 41(1), 87-108.

Hoy, W. K. and Sweetland, S. R. (2001). Designing better schools: the meaning and nature of enabling school structure. Educational Administration Quarterly, 37, 296-321.

Hoy, W. and Sweetland, S. (2000). School bureaucracies that work: enabling, not coercive. Journal Of School Leadership, 10(6), 525-541.

Işıkhan, V. (2004). Stress and ways of coping in working life. Sandal Publications.

Kalağan, G. and Güzeller, C. O. (2010). Investigation of teachers' organizational cynicism levels. Pamukkale University Journal of Education Faculty, 27, 23-97.

Kanungo, R. N. (1982). Measurement of job and work involvement. Journal of Applied Psychology, 67(3). 341-349.

Karakuş, M. (2013). Emotional intelligence and negativefeelings: a gender specific moderated mediation model, Educational Studies, 39(1), 68-82.

Karakuş, M. and Çankaya, İ., H. (2012). Testing a model regarding psychological violence subjected by teachers. Hacettepe University Journal of Education Faculty 42, 225-237

Karasar, N. (2005). Scientific research method. Nobel Publication Distribution. 
Karip, E. (2005). Globalization and lisbon education 2010 targets. Educational Administration in Theory and Practice, 42, 195209.

Kılıç, T. (2013). A model proposal regarding the individual and collective competence process, its determinants and results. [Unpublished Doctorate Thesis] Balıkesir University.

Kirkman, B.L. and Rosen, B. (1999). Beyond self-management: antecedents and consequences of team empowerment. Academy Of Management Journal, 42, 58-74.

Kraimer, M, L. (1997). Organizational goals and values: a socialization model. Human Resource Management Review, 7 (4), 425-447.

Kristof, A. L. (1996). Person-organization fit: an integrative review of lt conceptualizations, measurement, and implications. Personnel Psychology, March, 49(1):1-49.

Manion, J. (2005). From management toleadership: practical strategies for health care leaders. Jossey-Bass.

Maslach, C. and Jackson, S. E. (1981). The measurement of experiencedburnout. Journal of Occupational Behavior, 2, 99-113

Mathis, R. L. and Jackson, J. H. (2008). Human Resource Management (12th edition). Mason, $\mathrm{OH}$ : Thomson South-Western.

Mcguigan, L. and Hoy, W. K. (2006). Principal leadership: creating a culture of academic optimism to improve achievement for all students. Leadership And Policy In Schools, 5(3), 203-229.

Meyer, J. P. and Allen, N.J (1991). A Three-component conceptualization of organizational commitment. Human Resource Management Review, 1 (1), S. 61.

Meyer, J.P. and Allen, N.J. (1997).Commitment in the workplace. theory, research andapplication. Sage Publications

Morrison, E.W. and Milliken, F.J. (2003). Speaking up, remaining silent: the dynamics of voice and silence in organizations. Journal of Management Studies, 40 (6), 1353-1358.

Mumpower DL. (1964). The fallacy of the short form. J Clin Psychol, 20: 111113. 
Naus, F. (2007). Organizational cynicism on the nature, antecedents, and consequences of employee cynicism toward the employing organization. universiteit Maastricht [Unpublished Doctoral Thesis]. Maastricht.

Oldham, G, R. and Hackman J. R. (1981). Relationship between organizations strtucture and employee reactions: comparing alternative frameworks. Administrative Science Quarterly, 26(1), 66-83.

Öcal, H. and Aydın, O. (2009). Relationships between collective efficacy, selfefficacy and confusion perceptions and perceptions of success and expectations in sports teams. Journal of the Faculty of Letters, 26(2).

Öz, M. (2015). A field study on increasing the efficiency of internal audit in universities. [Unpublished Master Thesis]. Selçuk University.

Özer, N. and Dönmez, B. (2013). Reassesing the psychometrıc propertıes of the turkish version of enabling school structure scale. Pegem Journal of Education \& Instruction, 3(4), 2013, 57-68.

Piasentin, K. A. (2007). How do employees conceptualize fit? Development of a multi dimensional measure of subjective person-organization fit. Unpublished doctoral dissertation. University of Calgary.

Raykov, T. (1997). Scale reliability, cronbach's coefficient alpha, and violations of essential tau-equivalence with fixed congeneric components. Multivariate Behavioral Research, 32, 329-353.

Riggs, M.L. Warka, J. Babasa,B., Betancourt, R. and Hooker, S. (1994). Development and validation of self-efficacy and outcome expectancy scales for job-related applications. Educational And Psychological Measurement, 54, 793-802.

Rusbelt, C. A., Farrell, D. and Rogers, M. (1988). Impact of exchange variables on exit, voice, loyalty and neglect: an integrative model of responses to decline job satisfaction. Academy Of Management Journal, 31(3), 599627.

Sabuncuoğlu, E. T. (2007). Examining the relationships between education, organizational commitment and the intention to leave. Ege Academic Perspective, 7(2), 621-636

Schyns, B. Torka, N. and Gössling, T. (2007). Turnover intention and preparedness for change. Career Development International, 12(7), 660679. 
Smith, K.B. and Meier, K.J. (1994). Politics, bureaucrats and schools, public Administration Review, 54(4), 551-558

Smith GT, and McCarthy DM, Anderson KG. (2000). On the sins of short-form development. Psychol Assess, 12, 102-111.

Spector, P. E. (1997). JobSatisfaction: application, assessment, causes, and consequences, Sage.

Sulu, S. (2010). The role of business attitudes in the relationship between organizational injustice and business behavior, [Unpublished Doctorate Thesis], Gebze Institute of Technology Institute of Social Sciences.

Sümer, N. (2000). Structural equation models: Basic concepts and sample applications. Turkish Psychology Articles, 3(6) 49-74.

Taşkıran, E. (2011). Interaction between leadership and organizational silence The role of organizational justice. Beta publications.

Ulutaş, M., Kalkan, A. and Bozkurt, Çetinkaya, Ö. (2015). The effect of individual-organization fit on job satisfaction and organizational commitment. Business, Power Industrial Relations and Human Resources Magazine, 17(1), 141-160

Vance, R.J., Brooks, S.M. and Tesluk P.E. (1995). Organizational Cynicism, cycinal cultures and organizational change efforts. Paper presented 10th Annual Conference of the Society for Industr, al and Organizational Psychology, Orlando, FL.

Vilela, B. B., Gonzalez, J. A. V. and Ferrin, P. F. (2008). Person- organization fit, ocb and performance appraisal: evidence from matched supervisorsalesperson data set in spanish context, Industrial Marketing Management.

Wasti, S. A. (2000). Meyer ve Allen üç boyutlu örgütsel bağlllık ölçeğinin geçerlilik ve güvenirlilik analizi. 8. Ulusal Yönetim ve Organizasyon Kongresi Bildirileri, 401-410.

Yahyagil, Y. M. (2005). Birey ve organizasyon uyumu ve çalışanların iş tutumlarına etkisi. Öneri Journal, 6(24), 137-149.

Yücel, C. (1999). Bureaucracy and teachers' sense of power (Unpublished Doctoral Dissertation). Virginia Polytechnic Lnstitute And State University-Virginia. [Um1 Number: 3147768]. 
Zeynel, H. and Çarıkçı, H. (2015). The effect of professional motivation on job satisfaction and organizational commitment: an empirical study on academicians. Journal of Süleyman Demirel University Faculty of Economics and Administrative Sciences, 20(3), 217-248 